\title{
Az óriás likacsosgomba (Meripilus giganteus Karst.) tartalomanyagainak vizsgálata
}

Sárközy András ${ }^{1}$, Béni Zoltán², Dékány Miklós², Zomborszki Zoltán Péter ${ }^{1}$, Papp Viktor ${ }^{3}$, Rudolf Kinga ${ }^{4}$, Hohmann Judit ${ }^{1}$, Ványolós Attila ${ }^{1}$

${ }^{1}$ Szegedi Tudományegyetem, Farmakognóziai Intézet, 6720 Szeged, Eötvös u. 6.

${ }^{2}$ Richter Gedeon Nyrt., 1103 Budapest, Gyömröi út 19-21.

${ }^{3}$ Szent István Egyetem, Kertészettudományi Kar, 1118 Budapest, Villány út 29-43.

${ }^{4}$ Kaposvári Egyetem, Agrár- és Környezettudományi Kar, 7400 Kaposvár, Guba Sándor u. 40.

Az óriás likacsosgomba (Meripilus giganteus) a Meripilaceae család hazánkban legelterjedtebb tagja. A faj leginkább bükkösökben fordul elő, parazita vagy szaprofita életmódot folytat. Bár fiatalon ehető, nem ízletes, emiatt nem széleskörűen gyǔjtött gomba. Korábbi farmakológiai vizsgálatok eredményei alapján az óriás likacsosgomba kivonata antibakteriális és antioxidáns hatással rendelkezik, azonban a tapasztalt hatásért felelős tartalomanyagokról igen kevés információval rendelkezünk. Munkánk célja volt az óriás likacsosgomba biológiailag aktív vegyületeinek izolálása, szerkezetmeghatározása és farmakológiai hatásának vizsgálata.

A vizsgálandó mintát több észak-magyarországi lelőhelyen gyűjtöttük 2016 őszén. A 12 kg gombát szobahőmérsékleten metanollal kivontuk, majd $n$-hexánnal, ill. kloroformmal folyadék-folyadék extrakciót végeztünk. Ezt követően a kloroformos frakcióból különböző elválasztástechnikai módszerek alkalmazásával (flash kromatográfia, normál és fordított fázisú HPLC, preparatív rétegkromatográfia) 6 komponenst izoláltuk, amelyek szerkezet-meghatározása spektroszkópiai módszerek (NMR és MS) segítségével történt. Az azonosított összetevők között ergosztán vázas és ceramid típusú vegyületeket, illetve hidroxi-zsírsavakat is találtunk. A komponensek antioxidáns hatását ORAC és DPPH módszerekkel vizsgáltuk. Munkánk folytatásaként a vegyületek antibakteriális hatásának vizsgálatát és a hexános frakció jellegzetes komponenseinek azonosítását tervezzük.

Témavezetők: Ványolós Attila (SZTE, Farmakognóziai Intézet) 